\title{
Multidimensionality and Non-Deductiveness in Deliberative Argumentation
}

Kock, Christian Erik J

Published in:

Anyone Who Has a View

Publication date:

2003

Document version

Peer reviewed version

Document license:

Unspecified

Citation for published version (APA):

Kock, C. E. J. (2003). Multidimensionality and Non-Deductiveness in Deliberative Argumentation. In F. H. V. Eemeren, J. A. Blair, C. A. Willard, \& A. F. S. Henkemans (Eds.), Anyone Who Has a View: Theoretical Contributions to the Study of Argumentation (pp. 155-171). Kluwer Academic Publishers. 
Multidimensionality and Non-Deductiveness in Deliberative Argumentation

Christian Kock

University of Copenhagen

In current argumentation theory, the focus is not often on deliberative argumentation as such. Many modern theorists tend to see argumentation as a homogeneous phenomenon. Even so, there has recently been a tendency to differentiate more, for example in the works of Douglas Walton, who has defined different types of argumentative dialogue. However, to understand deliberative argumentation better, we also need to differentiate in another way, namely on the basis of argumentative issues.

Aristotle did this when he defined the three main genres of rhetoric. And if we take a closer look at the nature of the issues in deliberative argumentation, several interesting implications will ensue. Deliberative argumentation will turn out to be at odds with assumptions widely accepted in current theories, such as pragma-dialectics and the model of "presumptive" reasoning advocated by Walton.

The essential fact about deliberative argumentation is that it is not about truth, but action. This fact has been cursorily acknowledged by some theorists, but hardly explored. Toulmin (1958), who makes a strong case for distinguishing between argumentative fields, nevertheless only considers arguments for claims like "Harry is a British citizen" and other constative propositions. Even Perelman and Olbrechts-Tyteca fail to make a consistent distinction between arguments about action and arguments about truth. On the one hand, they emphasize that deliberative argumentation is "oriented toward the future" and "sets out to bring about some action or to prepare for it by acting, by discursive methods, on the minds of the hearers" $(1969,47)$; on the other hand, they cloud the distinction by repeatedly speaking of "theses" presented for the audience's assent. Characteristically, to find acknowledgement that the issues in deliberative argumentation are not propositions or theses, we must go to the textbook literature, including the work that Toulmin co-authored (1979). Educators remember what theorists like to forget: deliberative argumentation is ultimately not about what is true, but about what to do.

A typical deliberative issue is (for the United States, at the time of writing), "starting a war on Iraq". Those who propose this action are making a proposal. It would be a categorial mistake to predicate truth, or for that matter falsehood, of a proposal. Proposals are not propositions (assertions, constative statements); they do not predicate that anything is the case.

Walton comes close to saying just that in his distinction between "practical" and "discursive" reasoning, when he states: "In the action type of critical discussion, the proposition is a practical ought-proposition that contains an imperative" $(1996,177)$. However, he blurs the distinction again by describing the deliberative issue as a proposition about what is "prudential". The issue in deliberative argumentation is not a proposition; it is a proposal. It does not predicate a state of affairs, nor what ought to be the case; it proposes an action. It is like proposing a toast, or proposing marriage to someone. Proposals cannot be true or false.

All this is not to deny that deliberative argumentation usually involves a great deal of constative propositions, e.g., "Iraq supports Al-Qaeda terrorists". Such a claim may indeed be used as an argument in favour of starting a war; but the ultimate issue at the top of the argumentative hierarchy is the decision on whether to take action in the form of war. Similarly, the issues of recent referendums in Europe have not been propositions, but proposals to adopt the common currency, or to accept the treaty of Nice. Such issues cannot be formulated as constative statements, and they cannot have truth-values. What we vote about is not the truth of a proposition, but the acceptance of a proposal. 
It may seem formalistic to insist on this distinction. But it has important implications. One of them is that, strictly speaking, there cannot be any logic of deliberative argumentation. This is because "logic" is about propositions, whereas deliberative argumentation is about proposals. And this accounts for another essential feature of deliberative argumentation, namely what we may call its multidimensionality.

This term means that arguments for or against a proposal may belong to a number of separate dimensions. If I propose marriage to someone, she might find me a prudential choice; but she might not love me. And even if she did love me, there would still be the fact that to marry her, I would have to break up my current family, which would be ethically questionable. So in deliberating upon my proposal of marriage, the chosen woman would have to do some mental juggling of arguments belonging to three dimensions: prudence, inclination, and ethics - and perhaps even more.

As we know from experience as well as from countless fictional narratives in literature, drama, or film, no logical rules can tell us how to put such heterogeneous arguments on a common denominator and calculate the net result. They lack commensurability. On the war against Iraq, too, there are many arguments on both sides, representing many dimensions. Some believe it will stabilize the region; others, that it will not. Both these arguments belong to the dimension of the socially advantageous, or, in Walton's term, the "prudential". But other arguments in the same debate belong to an ethical or religious dimension. Some argue that a pre-emptive attack on another country is an indefensible infringement of international law; others, that murderous dictators like Saddam Hussein must be deposed. Again, the dimensions that the various arguments belong to lack commensurability.

By contrast, in a discussion of whether a certain proposition is true - that is, whether a certain predicate can be truthfully predicated of a certain subject - we only have to consider one dimension, namely the one represented by that predicate.

The insight that deliberative rhetoric is multidimensional is as old as rhetoric itself, and it remains standard doctrine throughout antiquity. A brief overview of classical thinking on this theme may be in order here.

We find the multidimensional view of deliberation full-fledged in early Sophistic rhetoric, as in the Rhetorica ad Alexandrum, probably the oldest extant book on rhetoric, once thought to be by Aristotle. This text, which may antedate Aristotle's by a few years, offers a list of dimensions in deliberative argument: "he who persuades must show that those things to which he exhorts are just, lawful, expedient, honourable, pleasant, and easy of accomplishment" (1421b).

This type of advice has always struck some commentators as cynical or opportunistic in the way it suggests a battery of alternative lines of argument; ${ }^{1}$ it has an air of "try anything that works" or even "anything goes". But this seeming opportunism represents the fundamental insight that when we have to decide about contested actions, more than one general premise may come into play.

\footnotetext{
${ }^{1}$ Manfred Fuhrmann, who edited the only modern text of this work, has also written an introduction to classical rhetoric in which he indignantly dismisses it: "Seine Lehre ist radikal relativistisch - nicht aus der Fülle des eigenen Schöpfertums, wie die des Gorgias, sondern aus dem baren Opportunismus. Seine aalglatte Routine kennt nichts als eine Vielfalt von Situationen, die ein Redner zu meistern hat, und sie sucht für eine jede von ihnen möglichst viele und hilfreiche Argumente an die Hand zu geben, gute und schlechte, wie es sich trifft; eine Bewertung und Auslese nach irgendwelchen Prinzipien findet nicht statt" (Fuhrmann, 1984, 29).
} 
Aristotle, Plato's student, who saw his task as that of turning rhetorical textbook lore into a tekhne, went out of his way to make deliberative debate neatly one-dimensional by declaring that "[t]he end of the deliberative speaker is the expedient or harmful [to sympheron kai blaberon] ... all other considerations, such as justice and injustice, honour and disgrace, are included as accessory to this [symparalambanei]" (Rhetoric, I, iii, 5; 1358b).

Subsequent classical theory, however, continues to recognise at least two mutually independent dimensions in deliberative argument. The anonymous author of the influential Rhetorica ad Herennium (c. 90 B.C.) pays only a token tribute to one-dimensionality but effectually comes down on the side of the multidimensional view $(1954,3.3$.):

The orator who gives counsel will throughout his speech set up Advantage (utilitas) as his aim, so that the complete economy of his entire speech may de directed to it.

Advantage in political deliberation has two aspects: Security $($ tuta $)$ and Honour (honesta).

He goes on to subdivide each of these two, establishing a multi-layered hierarchy of values. However, the governing notion that Advantage is one notion is hard to see as more than a fudge when is has two "aspects" (partes) as potentially antagonistic as Security and Honour.

Young Cicero, writing his De inventione perhaps a few years later, explicitly recognises that deliberative argument has two dimensions, honestas and utilitas, whereas for each of the other two main genres there is only one: aequitas for the forensic genre, honestas for the epideictic. As also done in the ad Herennium, each of these is then subdivided into several component parts, and further complications are introduced in the form of feasibility, ease of accomplishment, necessity, and affectio (meaning a temporary change in the way some specific situation is evaluated) (De inventione, 2, 156-176).

Roughly similar analyses appear in Cicero's mature works. In the De oratore (written 55 B.C.) the experienced Antonius explains how, in deliberative matters, some debaters will emphasize aspects of utilitas, such as peace, wealth, power, or revenue, while others will talk about aspects of honestas, notably immortalis memoria and laus. Whichever of these one prefers, considerations of feasibility and necessity are always paramount (II, 334ff.). The shorter and more technical work De partitione oratoria (written towards 50 B.C.) presents a somewhat more complex analysis. Further considerations introduced here include the assessment of how important a course of action is (quam sit magnum), a factor which may argue for it although it may be hard of accomplishment. Also, Cicero points out that the hearers who are to decide on deliberative issues are of two classes: one which in all matters prefers dignitas (a term also used in De oratore, which may or may not be synonymous with honestas), and another which always looks for gain and for voluptas (De partitione, 83-89).

Quintilian devotes the whole of book III, chapter 8, of his Institutio to a discussion of the deliberative genre, declaring at the outset disagreement with those rhetoricians who see utilitas as its sole end. If one criterion were sufficient in deliberative debate, he would opt for Cicero's dignitas; however, we must recognize the fact that deliberative audiences will often consist mainly of uneducated people, and this implies that we should distinguish between utile and honestum. In another respect, too, deliberative argument is multidimensional: it is not, as some claim, restricted to questions belonging to the qualitative status; issues of conjecture and definition, and issues belonging to the various legal status are involved as well.

In the so-called "second sophistic" during the centuries following Quintilian, we find, as in the early sophistic reflected in the Ad Alexandrum, an unabashed recognition that 
deliberative rhetoric has a diversity of equal, incommensurable dimensions, and no attempt is made to make one of them the master dimension or common denominator of all. The meticulous systematizer of Hellenistic rhetoric, Hermogenes (c. 150 A.D.), has included deliberative argumentation in his stasis system under the name "the practical issue" (stasis pragmatikos), and he simply states that its "divisions" are the following: "legality; justice; advantage; feasibility; honour; consequence" $(1995,52)$. His work on invention gives a highly technical account of how any line of argument that one chooses may be systematically structured and "worked up" (ergasia). Conley rightly says of the Hermogenean system: "This is clearly a long way from the syllogism-based notion of rhetoric familiar from, say, Aristotle's Rhetoric" $(1990,56)$.

What is important to gather from this overview of classical thinking about deliberation is primarily the insight that unites all these thinkers, with the possible exception of Aristotle himself: deliberative argumentation has more than one dimension. How many dimensions or "topics" each thinker recognizes, how they are named, and what exactly is the structure of the conceptual hierarchy in which they are arranged, is not the issue here. Instead I wish to highlight the fact that with as soon as we have more than one dimension, we have, in principle, incommensurability.

We might add that even in a model which recognises only one master dimension, such as Aristotle's with its sympheron-blaberon axis, we find that the explication of what this implies takes us back to Aristotle's ethical key concept of eudaimonia - which he then proceeds to analyse in chapters 5 and 6 of his Book I. Chapter 7 presents a list of topoi for deciding which of two goods is the greater one. But even in such a system, incommensurability is inevitable. The very fact that there is a list of topoi for deciding which is the greater or lesser good implies that an action A may involve a greater good than B in relation to one topos - but at the same time a lesser good in relation to another topos. At the end of the day, the master rule that allows us to calculate objectively which good is the greater one eludes us.

A further important observation is that gradual differences in regard to a given dimension are recognized by all the classical rhetoricians. The dimensions they deal in are not exclusive dichotomies, like the true vs. false opposition. Not only in to regard to importance, as we saw in Cicero, but for all relevant dimensions it is clearly possible that a given action may have more or less of the quality designated by that dimension. The advantage that will accrue from a given action may be greater or lesser; it may be honourable, or dishonourable, to a greater or lesser degree; it may be more or less feasible.

Finally, both Cicero and Quintilian emphatically note that people differ in regard to the weight they will ascribe to each of the dimensions. So not only are there separate dimensions, on each of which the proposed action will be assigned a graduated evaluation; also, each of the individuals who are to evaluate will do their separate and subjective evaluations.

All in all, the kind of multi-dimensional theory typified by Hermogenes' list, or that of the Ad Alexandrum, which is practically the same, is, as we have now seen, mainstream thinking in ancient rhetoric. The diversity of such lists, and the absence of "truth" from them, were no doubt some of the aspects of sophistic doctrine that made Plato and others see rhetoric as opportunistic flattery and a method for turning black into white. We may compare this sophistic recognition of multidimensionality with the disillusioning discovery by the Pythagorean mathematicians of irrational numbers. (For example, the relation between the diagonal and the sides of a square is irrational. No mathematical calculation can find a common denominator, or "commensurability", between them.)

By contrast, economic cost and benefit, for example, are commensurable entities. Both have the same denomination: money; they may therefore be reduced to one coefficient. 
Not so with the various arguments that are advanced about deliberative proposals such as starting a war, adopting the Euro, banning abortion or capital punishment. In such matters, there is no algorithm for tallying up the pros and cons.

This is why the distinction between and propositions and proposals is important. With propositions, we may, in principle, have deductive validity. A proposition is one-dimensional in that it asserts one predicate, and that is why the truth of that predication may follow from the truth of the premises. A proposal does not assert anything, although several propositions representing separate dimensions may be asserted as premises for or against the decision to accept a given proposal.

As a consequence, in deliberative issues there can be no deductive inference from premises to acceptance. This point is central to Perelman's entire thinking about argumentation; indeed, he sees the defining feature of "argumentation", as opposed to "demonstration", in the fact that argumentation is "noncompulsive", i.e., that deductive inference is not possible. The following statement of this principle from one of Perelman's later writings squarely aligns "truth", as in propositions, with "demonstration", and "argumentation" with "decision", as in proposals:

In argumentation, it is not a matter of showing (as it is in demonstration) that an objective quality (such as truth) moves from the premises towards the conclusion, but rather it is a matter of showing that one can convince others of the reasonable and acceptable character of a decision, based on what the audience already assumes and based on the theses to which it adheres with sufficient intensity. $(1989,11)$

By contrast, in arguing for a proposition we may in principle make a deductive inference, i.e., make the truth of the premises "move towards the conclusion"; and this proposition may then be used in deliberative debate as an argument for adopting a given proposal. But at that stage there is no deductive inference. There will always be other arguments in the matter, pertaining to other dimensions, and there is no deductive way to reduce the multiple, multidimensional arguments to one common denominator and deduce a net result.

Perelman and Olbrechts-Tyteca anticipated this characteristic of deliberative argumentation. They pointed out that "the possibility of arguing in such a way as to reach opposite conclusions" will always exist "when the argumentation aims at bringing about an action which is the result of a deliberate choice among several possibilities" $(1969,46)$.

However, much current theory has failed to follow this lead. In pragma-dialectics, for example, some form of deductivism is central, i.e., a belief in a normative rule demanding that the conclusion should follow in a valid manner from the premises. One of the ten basic rules of pragma-dialectics states: "A party may use only arguments in its argumentation that are logically valid or capable of being validated by making explicit one or more unexpressed premises" (Rule 8 in van Eemeren et al., 1996, 284). But as we have just seen, because deliberative argumentation is about proposals and hence multidimensional, it does not allow for logical validity.

Pragma-dialecticians are aware of a difficulty here. A footnote to the passage just quoted states that valid is used in "a broader sense", so that there is no "dogmatic commitment" to deductivism. However, it never becomes quite clear in what broader sense "valid" is to be taken. There are sporadic comments, but they all deal with the kind of reservations about the validity concept that are internal to the purely formal definition, e.g., how to avoid granting "validity" to an inference where the conclusion tautologically repeats a premise. What we generally do not find in pragma-dialectics, however, is a clear recognition that arguments in, e.g., ethical or political debate may be perfectly good and legitimate, and yet not be valid in any sense resembling deductive validity. 
The qualification that arguments, if not logically valid, should be "capable of being validated by making explicit one or more unexpressed premises" does not fix this hole in the theory. The unexpressed premises thus imputed to arguers so that their arguments may be "validated" are, in many cases, premises that these people themselves would undoubtedly reject. For example, a British opponent of the Euro may believe in the argument that Sterling, as a symbol of national identity, should be preserved. But that person is not thereby committed to the premise that any symbol of national identity should always be preserved in any country or context. And only such a general premise would serve to "validate" his argument against the Euro. So the notion of "validating" arguments by reconstructing their unexpressed premises does not do justice to the way many people actually use arguments on deliberative issues.

Another example of a premise where this kind of validation would misrepresent the arguer's own standpoint may be cited from a televised debate discussed in Jørgensen, Kock \& Rørbech (1998). The issue was whether to ban surrogate motherhood arrangements. The opponent of this proposal was Ms. Pia Kjærsgaard (later to become leader of the antiimmigrant Danish People's Party, which has recently generated international attention). Her main argument was that a ban on surrogate motherhood would be a curtailment of personal freedom. Interestingly, this charismatic and powerful political leader lost the debate to a softspoken academic who argued that babies born by surrogate mothers might become merchandise. But what is more relevant in the present context is the fact Ms. Kjærsgaard would never accept a general premise rejecting every curtailment of personal freedom. After all, any law curtails personal freedom. For example, her party has recently helped introducing new laws severely restricting citizens' rights to bring foreign spouses to the country.

Several theorists who sympathize with pragma-dialectics have sensed that its deductivist position is in need of qualification or defence. One such theorist is Leo Groarke (1999), who states, with praiseworthy explicitness, "natural language arguments should be understood as attempts to formulate deductive arguments" $(1999,2)$. He points out, amongst other things, that validity in the relation between premises and conclusion only means that the conclusion preserves any certainty inherent in the premises, not that a certain conclusion can be drawn from uncertain premises. But even with this - perhaps rather obvious qualification, deductivism is still at odds with the kind of arguments found in deliberative debate. And the way Groarke speaks of "inductivism" as the only alternative to deductivism indicates that in fact he only has argumentation about propositions, i.e., constatives, in mind. The fact is that in deliberative debates we often hear arguments that are quite certain and legitimate, for example that if we adopt the Euro, we will not need to change our money when travelling to another member country; but in spite of such unassailable arguments, the conclusion, namely the adoption of the Euro, does not follow deductively (as a majority of Danish voters demonstrated when they rejected the Euro in a referendum in September 2000).

Another attempt to preserve some version of the normative validity requirement is based on the idea of arguments being presumptive or defeasible. Douglas Walton is the foremost exponent of this approach. However, the notion of presumptiveness is slippery. It is clear that presumptive reasoning is non-monotonic, in the sense that new arguments may come up so that debaters are no longer committed to the presumed conclusion. But what is the nature of this commitment to the presumed conclusion - as long as it lasts? It seems that there are two versions of this commitment, one weaker and one stronger. In the weak version, when an arguer offers an argument in support of a conclusion, then a burden of proof is shifted onto the respondent, who then has to question or attack the argument. By doing that, he can shift the burden back onto the other side. In the strong version of what presumption 
means, the respondent is committed to accepting the conclusion, in a presumptive way, unless he can find fault with the argument.

This latter meaning of presumption seems to be understood in the following statement by Walton, summarizing the views of van Eemeren and Grootendorst (1992): "If the hearer accepts the premises of the speaker's argument, and the argument is an instance of a genuine and appropriate argumentation scheme (for the type of dialogue they are engaged in), then the hearer must or should (in some binding way) accept the conclusion" (Walton 1996, 10). Walton goes on to say that this "does not appear to be "validity" in the same sense in which the word is familiarly used in deductive (or even inductive) logic". But still we find here the same general tendency as in the deductive model of argumentation: if an argument is "valid", then the hearer is in some way "bound" to accept the conclusion. Validity, even if it does not mean deductive or monotonic validity, means "bindingness" - although the precise nature of the binding commitment or burden is often hard to pin down.

I suggest that argumentation theory, at least as far as deliberative argumentation is concerned, needs to abandon the notion that the validity of an argument has to do with the conclusion being in some way binding. Plain deductivism, reconstructionism, and presumptionism are all versions of the deductivist way of thinking about argumentation. But for deliberative argumentation at least, this way of thinking is false. A look at any deliberative debate will show that the arguments used there may be perfectly good and legitimate, indeed that they may fully deserve the term "valid" - and yet the conclusion they support does not follow in any binding way. In most cases, not even the debater who uses a given argument in deliberation believes that the hearer should be bound by the conclusion. Moreover, respondents in deliberative argumentation often do not feel obliged to raising critical questions about their opponents' arguments, lest they should become bound to accepting their conclusion. This is not because they abandon their standpoint or shirk their duties as debaters. Just as often, it is because they acknowledge that the opponent has a legitimate argument; but, on the other hand, they believe they have arguments for their own standpoint that have greater weight.

The reason that deliberative debaters may think so is precisely that deliberative argumentation is multidimensional. This property implies that arguments may be perfectly good and yet not binding.

In a recent paper by van Eemeren himself, with Peter Houtlosser (2000), we find an excellent example of deliberative argumentation, illustrative of many of its central features. They quote a heated British debate on fox-hunting, which can be seen as illustration of how each side, precisely because of the multidimensionality of such debates, has legitimate arguments which carry some weight, but which cannot in themselves entail a conclusion.

The anti-hunters argue that foxhunting is cruel, and they draw an analogy to cockfighting and bear-baiting - both of which were banned long ago. The pro-hunters argue that a ban would unsettle popular rural traditions and have a divisive effect, "setting town against country". Both these arguments are legitimate and carry some weight, yet neither of them is sufficient in itself to entail a conclusion. Even many of those who would use one of these arguments in a debate over this issue are probably not ready to accept a "reconstructed" general premise that would make their argument deductively valid; even die-hard foxhunters hardly believe that any socially divisive policy should necessarily to be rejected. The abolitionist campaign in the United States 150 years ago was socially divisive and did set town against country; and even for an abolitionist like Lincoln himself, this argument no doubt was legitimate and had a certain weight. However, in the particular situation it was outweighed, for him and for many other Americans, by other considerations. Similarly, the cruelty argument is legitimate and yet not deductively valid. There are many cruel practices in our society, some of them traditional and some modern, but recognizing that they are cruel 
does not entail a commitment to having them all banned. Neither does the analogy to other cruel practices that have been banned entail such a commitment. One debater in van Eemeren and Houtlosser's article offers further analogies such as horse races and "the far larger cruelty of factory farming". However, many people who feel that there is indeed an amount of cruelty in horse racing and factory farming probably do not believe that they should eo ipso be banned. Thus, when theorists impute such an unexpressed belief to them in order to "validate" their argument, the theorists are at odds with how people actually think.

The example questions not only the deductivist account of argumentation, but also the presumptionist theory. That theory would hold that if a debater points out that foxhunting is cruel and argues that it should therefore be banned, then that presumption stands, and the opponent should then carry the burden of proof and refute the argument. But none of the profox-hunters in the debate seem to have tried to refute the cruelty argument, in fact they may tacitly have recognized its legitimacy; instead, they meet it with an argument belonging to another dimension, i.e., the social good of hallowed traditions and the avoidance of divisive laws. Thus an ethical argument is countered, not cancelled, with social arguments. One may see all these arguments as acceptable and having at least some weight - and many people probably do. This is tantamount to saying that none of them is logically valid or "binding", not even in the "presumptive" way.

A final, paradigmatic example may be in order. In an article titled "The Right to Live vs. the Right to Die: No Single Yardstick", columnist Ellen Goodman (1986) describes two cases of people who wished to be allowed to die by starvation. One was an 85-year-old man in Syracuse, N.Y., who had recently had a stroke, and who had deliberately stopped eating. The administrators of the nursing home where he lived wanted to force-feed him, and took the case to court. However, Justice Miller of the State Supreme Court ruled against them, writing in his ruling, "I will not, against his wishes, order this man to be operated upon and/or to be force-fed". Goodman comments that she approves of this ruling. The fact that the man wished to die of starvation was indeed a legitimate reason in favour of letting him die - but even so, it was not a reason that deductively entailed the decision.

Here Groarke's point about deductive validity being only certainly-preserving, not certainty-establishing, is irrelevant: the man certainly wished to die, and this was undoubtedly a legitimate argument, yet the decision did not follow deductively. It would obviously be false to "reconstruct" a general unexpressed premise underlying the Justice's decision (and Goodman's approval of it) to the effect that "all persons who wish to die of starvation should be allowed to do so". The premise we may reconstruct is rather that a person's wish to die of starvation is a reason in favour of letting that person do so. No more, no less.

That this is so is brought out explicitly by Goodman's second example: a 26-year old woman in California, severely handicapped by cerebral palsy, wanted to be allowed to starve herself to death. Yet here the judge denied her request. And Goodman agrees with this decision too. But there is no inconsistency. It is much more reasonable to say that in both cases, she (like the judges handling the cases) holds the premise, stated before, that a person's wish to die of starvation is a reason in favour of letting that person do so. No more, no less. It is a premise with some weight in both cases, but in neither case does this premise, however true and certain, deductively entail the conclusion. In one case, this reason is on the "winning" side of the argument; in the other case, on the losing side. In both cases, it is legitimate and has a certain weight.

In defence of the deductivist account, one might rightly point out that the patient's own wish is not the only premise in either of the two cases. The deductivist might then argue that when this premise is added to the other pertinent premises in each of the cases, then the conclusion in each of the two cases follows deductively. In other words, for the old man one 
would say something like this: his own wish, his advanced age and the nature of his illness together entail the conclusion that he should be allowed to die. For the young woman, her youth would be one of the premises that, in spite of her own wish, deductively entail the opposite conclusion.

It is easy to see how artificial such an account would be. How does one add up the premises favouring a certain conclusion, and how does one subtract the ones favouring the opposite conclusion? How old does one have to be to be allowed to starve oneself to death? How ill? We would need an algorithm assigning a specific weight to each premise, using the same common denominator for all the premises, and we would need a rule defining just how much weight on one side would be needed to constitute a deductively valid inference. The two cases in question were both brought to court and decided there, but obviously no such formula exists in the laws of the two states. Even if it did, it is obvious that a rule stating just how much weight is needed to make a conclusion deductively "valid" would be quite arbitrary; a different threshold value might just as well have been chosen.

For Goodman too, a whole set of considerations explains why she thinks differently of the two cases. But that is precisely the nature of making decisions, whether in court, in politics, in ethics or in everyday life. In a situation where several considerations or premises simultaneously play legitimate parts, the demand that conclusions follow deductively from their premises is doomed to failure, or forced to resort to artificial ad hoc constructions. The only natural way to account for argumentation in such situations is to say that a number of arguments or premises are all legitimate and relevant, but that there is no deductively valid link from the relevant premises to any conclusion.

Indeed, we might argue that the use of the term "valid" in logic is a misnomer, and that the term might be much better employed for precisely those arguments that are legitimate without being deductively valid or cogent. Instead, "valid" arguments would be those that speak with some weight for the conclusion.

If one follows Walton's account, one might object that these cases still allow of a semi-deductivist or "presumptionist" interpretation. A patient's own wish to die of starvation, we might say, creates a presumption that the patient be allowed to do so - unless there are other factors that negate this presumption. Thus we have a valid inference of the "presumptive" or "defeasible" kind.

The answer to this account is that there are always other factors. They do not arrive out of the blue; they are always there already. But in neither of the two cases do these other factors that may plead for the opposite decision negate the legitimacy of the patient's own wish. That wish remains a legitimate argument of some weight, even if we decide that there are other arguments of greater weight that plead for the opposite decision. The idea that we either have to negate and demolish an argument, or else accept the conclusion for which it pleads, is false.

The attentive reader will not have missed the fact that the two contrasted examples cited by Goodman do not strictly belong to the deliberative genre, but are in fact cases of judicial reasoning. However, this circumstance might actually be seen as an a fortiori argument for the thesis presented here: we see that even in legal argumentation, which is of course much more constrained than deliberative argumentation by the existence of explicit and binding rules (such as laws and other provisions), we find that decisions with deductive force are (often) not possible; even here we often find an array of arguments on both sides, belonging to several dimensions, so that there is no objective or deductive way of calculating the relative strength of the opposite cases. This fact has long been central to the thinking of leading theorists of legal reasoning, including Joseph Raz, Robert Alexy, and Aleksander Peczenik (cf., e.g., Alexy 1978, Raz 1986, Peczenik 1995). Essentially, it implies that "[a] reasonable legal argumentation is a special case of a reasonable moral argumentation" 
(Peczenik, 747). Accordingly, the "incommensurability" of values or dimensions entering into ethical, political and legal decisions has been the object of sustained theoretical reflection in recent years (cf., notably, the writers contributing to Chang 1998).

The two cases described by Goodman are thus telling examples of how the making of decisions in politics, ethics or law is better described by the term "casuistry", as defined by Jonsen and Toulmin (1988), than by a model based on the deductive application of general principles.

It seems that we need an alternative metaphor for thinking not only about deliberative argumentation, but more broadly about how we discuss decisions - instead of the old metaphors that have to do with "chains" of reasoning or lines of argument that "bind" the opponent.

The ancient forensic image of the scales in which opposing arguments are weighed is a good starting point, emphasizing as it does that deliberation is related to libra, the Latin word for scales. However, while this image is illustrative of some features of deliberative debate, it is misleading about others.

Some interesting aspects well illustrated by the "scales" image are:

(1) In deliberative debate there is no deductive or "valid" demonstration of the claim, in the sense of "valid" defined by logic. Indeed, deliberative debaters often do not proceed from "premises" to "conclusion", as logicians do, but the other way around, i.e., they begin with a standpoint for which they then try to find arguments. To apply the scales image, people generally have a preconceived wish to tip the scales one way or the other, and they look for weights to throw into one of the two pans.

(2) Arguments used by deliberative debaters defy evaluation by binary standards such as valid/invalid, or sound/unsound; in deliberative debate there will generally be some arguments on both sides that have some weight. The assessment of the relative merit of arguments will typically be a matter of degrees.

(3) Although deliberative debaters sometimes pretend that their arguments make their proposals deductively valid or "binding", just as often they do not and would not pretend any such thing. This calls into question the way argumentation theorists "reconstruct" deliberative arguments by introducing "validating" premises.

(4) Deliberative debate is usually not linear, i.e., it is usually not limited to the establishment or refutation of one "clinching" argument. This is because there are no clinching arguments in deliberative debate, which again is why there are often several arguments on each side. Staking all on one line of argument in the belief that if the opponent accepts that, he must also accept the conclusion, is illusory.

The renaissance thinker Lorenzo Valla, a harsh critic of the medieval mode of thinking that aimed at logical proof in human or theological matters, made this point eloquently, if perhaps with off-putting belligerence, when he wrote, in a commentary on the medieval philosopher Boethius: "What is more inept than arguing the way the philosophers do, where, if one word is wrong, the whole case falls? The orator, on the other hand, uses many reasons of various kinds, he brings in opposites, he cites examples, he compares similar phenomena and forces even the hidden truth to appear. How miserable and inept is the general who lets the entire outcome of the war depend on the life of one single soldier! The fight should be conducted across the whole front, and if one soldier falls, or if one squadron is destroyed, others and still others are at hand. This is what Boethius should have done, but like so many others he was too deep in love with dialectics" (Valla, 1970, 113). ${ }^{2}$

\footnotetext{
${ }^{2}$ Quid enim ineptius philosophorum more ut si uno verbo sit erratum tota causa periclitemur? At orator multis et variis rationibus utitur, affert contraria, exempla repetit, similitudines comparat et cogit etiam latitantem prodire veritatem. Quam miser ac pauper imperator est
} 
All this is well illustrated by the "scales" image. However, even more interesting are certain features of deliberative argumentation that this image misrepresents:

(5) The decision on a deliberative issue cannot be deductively inferred by adding and subtracting the respective weights on the two sides. Arguments in deliberative debate may lack commensurability, i.e., they cannot be put on a common denominator in any binding way. Attempts to tally up the relative merits of alternative proposals in an objective fashion, e.g., in terms of economic cost and benefit, are thus illusory.

(6) This is because the weight of each argument is a subjective or "phenomenological" property relative to each member of the audience. As we saw, one may acknowledge that foxhunting has some social value, and at the same time feel that the suffering inflicted on the foxes argues against foxhunting with greater weight. But for the person sitting next to you it might be the other way around.

(7) However, even if there is no binding or formal way to define a "common denominator" for the pros and cons on a given deliberative issue, people nevertheless may have to decide between the two sides. And somehow they manage. Sometimes they even change sides after listening to argumentation. Apparently they do find a way to put the arguments on the same scales and assess which side has more weight. But this cannot be done formally; which way the scale tips is, for each person, a "phenomenological" property, resulting from the total impact of all the rhetorical stimuli which that person has received. In deliberative argumentation gravity, too, is relative. Weight in deliberative argumentation is a matter of degrees: deliberative arguments are not either valid or invalid, but have more or less weight. Moreover, that weight is relative to the person who judges it, and that person's judgment is influenced by the rhetoric that is used to either enhance or reduce that weight. Enhancing the weight of an argument is what Aristotle called "auxesis" and Latin rhetoricians "amplificatio"; reduction is "meiosis". The insight that the weight of an argument may be enhanced or reduced by degrees, and for each member of the audience individually, is one of the defining features of rhetoric; the insight that arguments belong to many dimensions is another.

The very fact of multidimensionality in deliberation, which prevents deduction in any form, also necessitates rhetoric. Deliberative argumentation is full of arguments on both sides that all have a certain weight - except that their weight is anything but certain or definite, but changeable and relative.

An important qualification is in place here. The present account of the "logic" of deliberative argumentation does not include the view that any argument proffered in any deliberative debate has some weight. The account given here has as its central tenet that arguments in deliberation belong to several dimensions and that this is one reason why deductive validity is not a relevant yardstick in the evaluation of such arguments. However, it does not follow from this that no concept of validity should be applied, nor that no arguments are ever "invalid". An account with such implications would be not only counter-intuitive but also pernicious. Pragma-dialectics is right in insisting that there is a need for at set of rules stating which speech acts are permissible and which are more or less blameworthy in a critical exchange. My point of departure has been that at least one of the standard rules of pragma-dialectics, and probably some of the others, must be rewritten if we are to have an adequate and useful tool for modelling deliberative debates. But the normative thrust of the pragma-dialectical account must be preserved. Argumentation specialists critically need

qui omnem fortunam belli in anima in unius militis ponit! Universitate pugnandum est et si quis miles concidit aut si qua turma plofligata est, alia subinde atque alia sufficienda. Hoc modo agendum Boethio erat, qui ut plurimi alii nimio amore dialectice deceptus est. 
conceptual tools for the normative monitoring of, and critical intervention in, ongoing political and social debates.

Construction of a conceptual basis for such practically oriented monitoring and intervention is well under way among argumentation specialists belonging to many orientations, such as pragma-dialectics, Informal logic, and others. These efforts ought to be coordinated and strengthened. However, theoretical views which overlook the multidimensionality of social and political debate and which hold, e.g., that some form of deductive validity is an applicable value criterion, impede the effort to build a platform for the normative criticism of public debate.

Indeed, I believe that one of the main categories of blameworthy debate behaviour is the tendency on the part of politicians and other debaters to suggest that an argument of theirs entails a certain policy with deductive validity; or, in a looser formulation, a tendency to say or suggest that their own arguments have stronger force than is warranted. Typically we find debaters behaving as if it was the case that because the policy they propose may have this or that advantage, it therefore follows that it should be adopted. The point is such cases is precisely what has been the main point of this article: that an argument for a policy may be perfectly good, yet this is not equivalent to saying that the adoption of that policy follows deductively. This distinction is overlooked by theories committed to deductive validity in any form.

Similarly, the idea that the other side may have legitimate arguments of some weight seems abhorrent to many politicians. This might be the common denominator for another main category of blameworthy debate behaviour: the tendency to ignore, misrepresent or offhandedly dismiss any argument that can be made against one's own policies, or in favour of those of the opponent. Many citizens, by contrast, probably believe that on most contested issues, there is in fact something to be said on both sides. Such voters will want to know what it is and to get a chance to evaluate the relative merits of all reasonable arguments. Politicians who flatly deny or ignore that the opposition may have a point, maintaining that their own policies are unassailable, are not credible in such citizens' eyes, and they probably help promote the kind of democratic cynicism reflected in, e.g., dwindling election turnouts.

Argumentation theory should teach would-be deliberative debaters to acknowledge legitimate arguments on the opposite side. They would probably be more willing to do so if it were also made clear that the acceptance of some of the opponent's arguments does not deductively entail a commitment to the opponent's proposals or policies. In accordance with this principle, argumentation specialists should keep a vigilant eye on debaters who tend to suppress or misrepresent arguments made by the opponent; this is something pragmadialectics has always emphasized, and rightly so. And they should show that the necessary function of deliberative debate is to identify, in Aristotle's phrase, "the available means of persuasion" (cf. Rhetoric 1355b) on both sides, thereby helping audiences form their own individual assessments of their relative weight. This would in turn help democracies sustain the credibility of political processes currently threatened by polarization, non-participation, and cynicism.

References

Alexy, Robert (1978). Theorie der juristischen Argumentation. Frankfurt a.M.: Suhrkamp.

Conley, T.M. (1990). Rhetoric in the European tradition. Chigaco: The University of Chicago Press.

Aristotle (1926). Volume xxii. The art of rhetoric. Translated by J.H. Freese. (Loeb Classical Library, 193.) Cambridge, Mass.: Harvard University Press. 
Aristotle (1937). Volume xvi. Problems, books 22-38. Rhetorica ad Alexandrum. Translated by W. S. Hett, H. Rackham. (Loeb Classical Library, 317.) Cambridge, Mass.: Harvard University Press.

Chang, Ruth (ed.). 1998. Incommensurability, incomparability and practical reason. Cambridge: Harvard University Press.

Eemeren, F.H. van, \& Grootendorst, R. (1992). Argumentation, communication, and fallacies. Mahwah, New Jersey: Lawrence Erlbaum Associates.

Eemeren, F.H. van, Grootendorst, R., \& Snoeck Henkemans, F. (1996). Fundamentals of argumentation theory: a handbook of historical backgrounds and historical developments. Mahwah, New Jersey: Lawrence Erlbaum Associates.

Eemeren, F.H. van, \& Houtlosser, Peter (2000). Argumentation, interpretation, rhetoric. http://www.argumentation.spb.ru/2000 1/papers/1 2000p1.htm.

Fuhrmann, M. (1984). Die antike Rhetorik: eine Einführung. München: Artemis-Verlag.

Goodman, E. (1986). The right to live vs. the right to die: no single yardstick. In W.F. Smith \& R.D. Liedlich (Eds.), From thought to theme. A rhetoric and reader for college English. Eighth Edition (pp. 386-388). San Diego: Harcourt Brace Jovanovich.

Groarke, L. (1999). Deductivism within pragma-dialectics. Argumentation, 13, 1-16.

Heath, M. (1995). Hermogenes on issues: strategies of arguments in later Greek rhetoric. Oxford: Oxford university Press.

Jonsen, A., \& Toulmin, S.E. (1988). The abuse of casuistry: a history of moral reasoning. Los Angeles: University of California Press.

Jørgensen, C., Kock, C., \& Rørbech, L. (1998). Rhetoric that shifts votes: an exploratory study of persuasion in issue-oriented public debates. Political Communication, 15, 283-299.

Peczenik, Aleksander. 1995. "Argumentation in ethics, legal dogmatics and legal practice". Argumentation 9 (1995), 747-756.

Perelman, C., \& Olbrechts-Tyteca, L. (1969). The new rhetoric: a treatise on argumentation. Translated by John Wilkinson and Purcell Weaver. Notre Dame: University of Notre Dame Press. (Original: Traité de l'argumentation: la nouvelle rhétorique (1958). Paris: Presses universitaires de France.)

Perelman, Chaïm (1989). "Formal logic and informal logic". (French original written 1981.) In Michel Meyer (ed.): From metaphysics to rhetoric. Dordrecht (Kluwer Academic Publishers), 9-14.

Raz, Joseph (1986). The morality of freedom. Oxford: Clarendon Press.

Toulmin, S.E. (1958). The uses of argument. Cambridge: Cambridge University Press. 
Toulmin, S.E., Rieke, R., \& Janik, A. (1979). An introduction to reasoning. New York: Macmillan.

Valla, L. (1970): De vero falsoque bono. Critical edition by Maristella de Panizza Lorch. Bari: Adriatica Editrice.

Walton, D. N. (1996). Argumentation schemes for presumptive reasoning. Mahwah, N.J.: Lawrence Erlbaum Associates. 